\title{
The social consequences of indenture system and aftermath in Fiji: an accountability study
}

\section{Ram Karan}

Fiji National University, Suva, Fiji

Email: ram.karan@fnu.ac.fj

\section{Umesh Sharma*}

School of Accounting, Finance and Economics,

Waikato Management School,

University of Waikato,

PB3105, Hamilton 3240, New Zealand

Email: ups@waikato.ac.nz

*Corresponding author

\begin{abstract}
This study examines the social consequences of the calculative practices used to control the indentured labour and its aftermath in Fiji. Although the indenture system in Fiji was officially abolished in 1917 and the indentured labourers became 'free settlers', they and their descendants continued to toil on sugar cane farms in much the same way as under the initial indenture system, just as slavery continued in different forms after slavery was officially abolished in many parts of the world. To ensure that the descendants of indentured labourers remained unskilled and continued to work on the cane farms the colonial government had a policy of not educating the children of indentured labourers. However, the determination of the visionary descendants of indentured labourers to engage in self-help education rising from humble beginnings to provide primary, secondary and tertiary education became the most powerful liberator of all.
\end{abstract}

Keywords: indentured labour; slavery; governmentality; eviction; self-help education; coups; Fiji.

Reference to this paper should be made as follows: Karan, R. and Sharma, U. (2021) 'The social consequences of indenture system and aftermath in Fiji: an accountability study', Int. J. Critical Accounting, Vol. 12, No. 1, pp.17-29.

Biographical notes: Ram Karan is a Professor of Accounting at the Fiji National University. His research interests are in business ethics, taxation and financial accounting.

Umesh Sharma is an Associate Professor of Accounting at the University of Waikato in New Zealand. His research interests are in management accounting, accounting history, sustainability accounting and accounting education. He has published his work in leading journals such as management accounting research, accounting history, qualitative research in accounting and management, accounting forum, amongst others. 


\section{Introduction}

Accounting control has been identified as 'ultimately ideological' [Tinker, (1985), p.10; James and McKenzie, 2018), working to the dissatisfaction of certain social interests while legitimising and empowering others (Arnold and Hammond, 1994). It is vital to explore the social consequences of accounting controls, which are relevant in the implementation of indentured labour schemes. The indentured system was officially abolished in 1917. Although abolition involves formally putting an end to some generally accepted system or practice, the systems and practices in place may take decades or centuries to gradually phase out or even never cease completely. Some oppressive systems may therefore be abolished but the oppressed may not be liberated for a very long time. Liberation involves setting someone free from imprisonment, slavery or oppression. Slavery, for example was officially abolished on 18 December 1865 by adopting the 13th Amendment into the US Constitution, ensuring that "neither slavery nor involuntary servitude... shall exist within the United States, or any place subject to their jurisdiction" (Slavery Abolished in America, http://www.history.com/this-day-inhistory/slavery-abolished-in-america).

Abolition of slavery, however, did not ensure freedom from slavery in the USA. The process of rebuilding the southern states without the slaves during the Reconstruction Period (1865-1877) presented new challenges. "Under the administration of President Andrew Johnson in 1865 and 1866, new southern state legislatures passed restrictive 'black codes' to control the labor and behavior of former slaves and other African Americans" (Reconstruction, http://www.history.com/topics/american-civil-war/ reconstruction).

The new form of control for the industrialists to build wealth on the bound labour of black included 'the convict lease system' (Forde and Bowman, 2017). Black men and sometimes women and children were arrested for petty offences including vagrancy (the 'crime' of being unemployed) to keep them tied to their former owners' plantations and farms and leased to private companies (ibid.).

When the convict lease ended in the early 20th century, it was replaced in many states by another racialised and brutal method of using convict labour: the chain gang - a group of convicts chained together especially to work outside a prison (ibid.). It has therefore been said "The 13th Amendment did not abolish slavery but rather moved it from the plantation to the prison" (Chan, 2015). As the system benefited the companies, the state and national economy as well, the federal government passed numerous opportunities to intervene (ibid.).

Abolition of slavery has thus continued in different forms even to this day. For example, it is said that "in 2015, the 2 million (largely Black) people incarcerated in America are legally considered slaves under the constitution. As a result, they can and are forced to work for pennies an hour with the profits going to counties, states and private corporations including target, revlon and whole foods. In fact, there are more Black people enslaved today than in 1800" [Chan, (2015), p.2].

The abolition of indenture has a similar but perhaps less cruel history. A form of indenture system known as 'servants in husbandry' existed in the 17th-century England where "youth of both sexes, lived and worked in the households of their masters, typically on annual contracts" [Galenson, (1984), p.3]. When Virginia Company found it difficult to recruit a sustained flow of adult workers it transported the institution of 'servants in husbandry' to its US colonies which lay the origins of the system of 
indentured servitude (ibid.). Servitude thus became a central institution in "the economy and society of many parts of colonial British America. Due to reduced supply and rising cost of white indentured laborers during the late seventeenth century, indentured laborers in America were gradually replaced with African slaves (ibid. p.11).

However, while the indenture system was disappearing from the USA, the abolition of slavery in the British West Indies in the 1830s gave rise to a renewed demand for indentured labour (ibid. p.14). In 1838, indentured Indians began to arrive in British Guiana and other British colonies (ibid.). By the end of indenture system in 1917, about two million Indian indentured labourers were transported to 19 British colonies [Indentured labour from South Asia (1834-1917), http://www.striking-women. org/module/map-major-south-asian-migration-flows/indentured-labour-south-asia-18341917.

The first shipload of 463 Indian indentured labourers arrived in Fiji aboard the ship Leonidas on 15 May 1879 (Indian Indenture Ships to Fiji, https://en.wikipedia.org/wiki/ Indian_indenture_ships_to_Fiji). The last ship SS Sutlej arrived on 11 November 1916 with 888 indentured labourers. Between 1879 and 1916, a total of 42 ships made 87 voyages, carrying 60,965 Indian indentured labourers and 60,553 reached Fiji (ibid.). The indenture system finally came to an end in 1917 when the British Government prohibited the transportation of debtors from India as servants (Sharma and Irvine, 2016). However, although the indentured labourers became 'free settlers', they and their descendants remained contractually bound to continue to toil in much the same way as under the indenture system. Abolition of indenture was only the beginning of a long struggle for liberation from indenture. The research question being asked is: what were the social consequences of calculative practices implemented to control indenture system? What were the impact of such calculative practices on post indenture labour and their descendants? This paper examines the milestones in this struggle to liberation from indenture system continuing in different forms. The study is motivated by the acknowledgement in academic literature that accounting controls produce social consequences (Arnold and Hammond, 1994) with Fiji chosen for the field study because of its extensive use of indenture labour over a defined period and also because the two authors are descendants of indentured labourers in Fiji, thereby bringing greater insights into the research.

\section{Research method}

We relied on secondary data to conduct this study. Historical information on indentured labour was accessed from the National Archives of Fiji in Suva between 2015 and 2018. These records included documents from colonial secretary's offices, and literature on indentured labour and Indians in Fiji. We also draw on published first-hand account of indentured worker's experiences by examining an account written in 1914 in Hindi by Totaram Sanadhya, an indentured labour and later translated into English by the Fiji Museum. Websites on various Indian cultural organisations were also visited such as Arya Samaj, Sanatan Dharam, Islam, Sikh and Sangam ${ }^{1}$ organisations in Fiji.

This archival data enabled us to capture a contextual understanding of the social phenomena under study (Carnegie and Napier, 1996), including the Fijian colonial setting and the employment of indentured workers and their livelihood in Fiji later. 


\section{A governmentality perspective}

Foucault's (1991, p.102) notion of governmentality is as an "ensemble of institutions, calculation and tactics" designed and deployed to ensure certain ends are met. This inculcates not only governing 'men' but also governing "men in their relation to customs, habits, ways of acting and thinking" [Foucault, (1991), p.93].

The style of governance is concerned with exercising control at a distance as opposed to the threats of violence that characterised previous ages (Foucault, 1979). Foucault's (1979) portrayal of disciplinary regimes involves a continuous and comprehensive surveillance of individual conduct (Armstrong, 1994).

Accounting offers 'ready made' solutions to the problems of governing (Miller and Rose, 1990; Vicencio, 2018) and encourages action through incentive schemes and funding mechanisms (Preston et al., 1997). Accounting makes social practices visible, calculable, gradually manipulable [Vollmer, (2003), p.363] and operationally useful, indicating that it is much more than narrow technology (Miller, 1990).

Accounting enables investors and senior managers to hold subordinates, both managers and workers, 'accountable for capital' [Bryer, (2006), p.553]. However, it also has the power to effect change and to contribute to systems of domination, injustice and racism (Fleischman and Tyson, 2000). Accounting and monitoring systems are not neutral tools, serving an ideological function by legitimating the actions (Tinker, 1985; Arnold and Hammond, 1994). Being perceived to be a neutral technology, accounting can assist in the bracketing of questions of moralty, having the power to effect change and to contribute to systems of domination and injustice (Kim, 2004; Hooks and Stewart, 2007; Sharma, 2013; Lawrence et al., 2010; Low et al., 2013; Sharma and Hoque, 2001).

\section{Findings}

\subsection{The control of indentured labour on Colonial Sugar Refining Plantations (1879-1916)}

Accounting technologies contributed to the control of labour on Fijian plantations during the period of indenture system. The plantation system has been described as a class-structured system of organisation where labourers sold their muscular energy and was paid for its use in the service of surplus production (Ali, 2004). The indentured system lasted from 1879-1916. Labourers, contracted to work on plantations for five years, while not slaves, nevertheless lacked freedom and were effectively captives. The social and political context therefore provided an environment conducive to capitalist exploitation, and accounting, as a calculative technique defined the space and ground rules whereby this would be enacted [Bryer, (2006), p.595].

Consistent with its drive to contain cost and increase profitability, Colonial Sugar Refinerys Fiji (CSR) operations were compared with its operations elsewhere. For the six months that were ended 30 September 1910, the first time comparative figures were made available, CSR's Australian refineries and mills yielded a net profit of $£ 126,714$, while the profit from its Fiji and New Zealand was $£ 70,000$ (CSR A 3.0/2/9). For the six months to 30 September 1914, the profits for Australian operations had dropped to $£ 121,360$, while the profit from its Fiji and New Zealand operations had increased to $£ 135,000$ (CSR F 1.0/2/4). As the greater part of the capital used in the New Zealand and 
Fiji, operations was invested in the Fijian mills, it is likely that much of the improvement was due to better results from Fiji (Maynagh, 1981).

Implementation of tasking as a performance measurement system meant that labourers were sometimes not paid for completing onerous tasks set. Thus, the labourers received very low pay, remained poor and relied on subsistence farming to survive (Sanadhya, 1914).

The indenture system was abolished in 1917 and the Indian labourers were allowed to own small estates of sugar cane farms. However, there were grievances as the Indian labourers were not compensated fairly for their produce. The millers actually took a greater chunk of the profits and this was not passed on to the growers in form of increased payment for the labourers produce.

\subsection{The award of the Rt. Hon. Lord Denning}

How indenture continued after indenture was abolished was succinctly described by Lord Denning. Although the growers had gradually emerged from a state of servitude to being farmers in their own right, and were seen to be completely free, many still felt traces of their old bondage [Denning, (1970), p.4]. They felt that they were being exploited that gave rise to much bitterness. They were particularly aggrieved by the Eve contract (recommended by Eve Commission headed by Sir Malcom Eve) that they were forced to sign against their will in 1961 (ibid.). According to the millers the Eve Contract was simple to understand and fair and just to all parties. Lord Denning, however, found that not only none of the growers could understand it in the least, but the Eve formula gave a big slice of the cake (proceeds from sale of sugar) to the millers before ever it was divided. The formula was so complicated that only few of the growers' lawyers could fathom it. It required an expert accountant to understand what it was all about (ibid. p.5).

The millers received all the money from the sale of sugar and took out of it virtually all their costs as a first charge. They took out costs they incurred in the production of cane such as salaries of field officers, cost of research establishments, and running and maintenance of the rail transport system. They also took out all costs incurred in making sugar from cane, costs of running the mills during the crushing season, costs of maintenance during the slack season, costs of putting sugar in the bags, costs of storage and cost of transporting from the mill to the ship. They also added $11.5 \%$ of the total of these costs as their 'head office expenses'. The millers took out all these actual or estimated costs from the proceeds of sugar before the growers received anything (Ali, 2004).

Molasses, a bi-product was taken by the millers to be used in their distilleries in Australia. The Eve Commission had recommended the value of molasses not to be added to the proceeds of sugar. Instead, it was to be credited against the manufacturing costs at the rate of 50 shillings per ton. The growers were disadvantaged in two ways. First, under the Eve formula, two-thirds of this saving on manufacturing costs went to the millers and only one-third to the growers. Second, 50 shillings per ton was too low compared to the then market rate of 90 shillings per ton. While the growers were already disadvantaged by the formula, the low price of molasses ensured that their share of the benefit remained minimal.

Then they added another $3 \%$ of the revalued amount (present value) of the invested capital (not the original capital cost) as depreciation. For example, in 1957 the railway system operating from Lautoka was recorded at cost in the books at $£ 708,791$ (ibid. p.9). 
In 1957 , it was revalued up to $£ 1,693,296$. Similarly, the telephone system stood at cost of $£ 20,311$ (ibid.). In 1959 , it was revalued to $£ 96,000$. Overall, the value of the assets before revaluation was $£ 5,548,364$. After revaluation they were put at about twice as much, i.e., $£ 11,269,526$ (ibid.). Depreciation before revaluation would have been $£ 166,451(£ 5,548,364 \times 0.03)$ but after revaluation it more than doubled to $£ 338,085$ $(£ 11,269,526 \times 0.03)$.

Generally in accounting practice depreciation is shown as a non-cash expense in the income statement to recognise a diminution in the value of capital assets. There is no cash inflow or outflow. In this case, however, depreciation was used not only to siphon off actual cash from the proceeds of sugar before sharing with the growers but the millers siphoned off more than twice as much just by revaluing the capital assets. The growers suspected that "the millers were making concealed profits in one way or another" (ibid. p.10). With the use this accounting illusion in this case, however, the millers defrauded the growers in full view of the growers' representatives with impunity.

The indenture system was abolished, but like slavery, the sugar industry continued with new forms of controls over labour and earnings. One such method was an unfair contract they the growers were forced to sign against their will. Another was deliberately not adding the value of molasses to the proceeds of sugar. The third was where the millers took out all their expenses from the proceeds of sugar before the growers received anything. And the fourth was using accounting illusion of depreciation to overtly siphon off a good part of the proceeds of sugar before sharing the leftover with the growers.

Lord Denning came to the conclusion that the value of molasses was to be added to the proceeds of sugar and the total to be split into 65\% growers' share and $35 \%$ millers' share.

This was unacceptable to the millers, Colonial Sugar Refining Company (CSR). The Fiji Government bought their interest and started operating the mills under a newly formed public enterprise the Fiji Sugar Corporation in 1973 and CSR left the country the same year. "Sugar cane price paid to growers increased from $\$ 9.76$ per tonne in 1973 to $\$ 20.90$ per tonne in 1974 i.e. 114\% increase. Growers regarded the Denning Award as much fairer than the Eve Award. The Denning Award, however, was to last only for a decade" [Reddy, (2003), p.268]. Then in 1975, the growers' share was increased from $65 \%$ to $70 \%$ (ibid.). From 1980 to 1989 , the grower-miller relations were governed by the Sugar Advisory Council (SAC) contract. The SAC contract was similar to the Denning contract except with the growers' share being $70 \%$ (ibid.).

During this period, the standard of living of most cane growers improved like never before. They bought tractors to replace the bullocks and horses, trucks to cart cane, cars to travel to towns and their grass thatched huts transformed into timber and iron or concrete and iron homes. Apart from sending their children to the village schools as usual, they were also able to afford to send their children to better schools in towns and cities and not only to the only university in Suva but to universities abroad as well. In short, not only their life completely transformed but many of their children were also freed from the fetters of continuing indenture in the sugar cane farms. Years later, many of these educated children have taken their parents out of the cane farms to live with them not only in towns and cities within the country but abroad as well.

After review of the proceeds sharing formula in the late 1980s and early 1990s, it was replaced with the Master Award (awarded by Justice Kermode) which provided for proceeds of sugar to be shared in the ratios shown in Table 1. 
Table 1 Sugar proceed sharing ratios

\begin{tabular}{lcc}
\hline Total sugar produced & Growers' share & Miller's share \\
\hline Up to 325,000 tonnes & $70 \%$ & $30 \%$ \\
$325,000-350,000$ tonnes & $72.5 \%$ & $27.5 \%$ \\
Tonnes in excess of 350,000 & $75 \%$ & $25 \%$ \\
\hline
\end{tabular}

Source: Reddy (2003, p.268)

While the rise in the growers' share of the proceeds of sugar might give the impression that the growers have become increasingly better off in recent years, the reality might be quite different. Sugar production actually decreased in recent years. In 2006, sugar output rose to 310,000 tonnes from around 289,000 tonnes in the 2005 season (RBF Quarterly Review, 2006). Then, it steadily declined to about 132,000 tonnes in 2010 (RBF Quarterly Review, 2010). Production then rose again reaching 226,230 tonnes in 2014, 221,934 tonnes in 2015 and again declining to 139,502 tonnes in 2016 (RBF Quarterly Review, 2014, 2015, 2016). This represents almost 55\% decline in sugar production since 2006 and hence a similar decline in the earnings of both the growers and the miller.

Since the production did not exceed 325,000 tonnes in this decade, then according to the sharing ratios in Table 1, the growers obviously not only could not have received more than $70 \%$ of the proceeds of sugar, but actual dollar amounts received by both the growers and the miller steadily diminished in this period. Why this has happened is no secret. It is well known that the sugar industry is currently inundated with numerous problems [Reddy, (2003), p.268].

The problems are on the sides of both the growers and the miller. On the growers' side, the major problems include declining production, ageing farmers, rising cost of inputs, serious shortage of farm workers and cane cutters and an apparent unwillingness or inability to adopt better production and harvesting practices. For the miller (FSC), major problems include low production, inadequate factory capacity, rising cost of production, high fixed cost, lack of skilled personnel, deteriorating rail transport system and declining sugar quality (ibid.). Loss of preferential sugar markets and volatility in world sugar prices are other major problems.

It can now be seen that while Denning's Award, and subsequent awards, gave much relief from ongoing fetters of indenture to the descendants of indentured labourers, the growers now faced both new prospects and new problems. The prospect was that they could be liberated from continued indenture, but the problem was that it could happen not only at the expense of a complete demise of the sugar industry but also at a complete loss of their livelihoods.

\subsection{The coups of 1987 and 2000}

Remarkably, the first coup in Fiji was carried out on 14 May 1987 - exactly 108 years after the first shipload of Indian indentured labourers came by Leonidas and set foot in Fiji in 1879 (Gopal, 2014). Although whether this day was deliberately chosen for the coup or it just happened by chance is not known, the ominous coincidence will always remain of special significance. While the descendants of the Indian indentured labourers were emigrating gradually for a long time, it was immediately after this May day that they started fleeing overseas in exceptionally large numbers. 
The first coup deposed the government of Prime Minister Timoci Bavadra which was followed by a second coup on 28 September to end the Fijian Monarchy and the third coup on 7 October proclaimed Fiji as a republic (1987 Fijian Coups D'état, https://en.wikipedia.org/wiki/1987_Fijian_coups_d\%\%C3\%A9ta). As racial tensions continued to escalate, "in May 2000, armed gunmen held (Chaudhary) government ministers hostage for 56 days and coordinated racial attacks against Indo-Fijians from the parliament" (Ramesh, 2007).

Extremists took to street-protesting, bullying Indians who stood in their way, burning Indian houses and businesses and looting Indian shops (Sherborne, 2008). As the coup-culture ravaged the economy, Fiji's business and professional classes fled the country. Following the first coup, more than 120,000 people - mostly Indians, the skilled farmers and experienced merchants emigrated (ibid.).

It was reported that 300 families from around the town of Labasa were evicted before the end of 2003 on the expiry of their leases on indigenous-owned land and more small farmers were dismantling their homes to move on (300 Fiji Farmers Reported Evicted in Vanua Levu Lease Expiry, http://www.radionz.co.nz/international/pacific-news/146302/ 300-fiji-farmers-reported-evicted-in-vanua-levu-lease-expir). Distraught members of several families who were dismantling their homes after 30 years on their land, said they were leaving crops behind and did not know where to go. Northern regional manager of the Native Land Trust Board said over eleven hundred tenants in Vanua Levu whose leases had expired had moved elsewhere (ibid.). A Ba chief, Adi Sainimili Cagilaba, said if there was no land to plant sugar cane, the industry would die and many people would be out of jobs (ibid.).

New refugee colonies were to be established for farmers evicted from their farms by the Native Lands Trust Board (Refugee Colonies for Evicted Farmers in Fiji, 2000). The National Farmers Union announced that a new colony would be established in Nanuku Rakiraki before the end of the month. Union President, Krishna Chand Sharma said that similar refugee camps would be established in Tavua, Ba, Lautoka, Nadi and Sigatoka. The NFU had one refugee camp already running in Valelawa in Vanua Levu (ibid.).

That same year, over 700 leases in the sugar cane areas had not been renewed. Most of the farmers in Fiji harvested between 100 and 150 tonnes of cane. At the then market price of cane, farmers' gross revenue was between $\$ 5,000$ and $\$ 8,000$ per annum from which all farming, harvesting and transportation costs had to be deducted leaving farmers in perpetual indebtedness and below the official poverty line (ibid.).

In 2016 , it was reported that about 77,794 or $7 \%$ of Fiji's population was living in 200 squatter settlements around Fiji (Simmons, 2016). While many squatter settlements have existed for decades prior the coups, a good number of the new comers are those who were evicted from the sugar cane farms. Although still living in crowded shacks and earning a living from menial jobs they now have tap water, electricity and television and are happy to have been evicted from the cane farms responsible for their continued indenture. For them, the coups were apparently a blessing in disguise.

\subsection{Self-help education (1874-2016)}

For the first 30 years of colonial rule in Fiji, the colonial government neither encouraged nor discouraged education of local population [Moag, (1978), p.11]. For European children, however, schools were provided in Levuka (from 1879) and Suva (from 1883), while native education was sustained and discharged by the missions. Although by 1900 , 
there were schools in most Fijian villages offering up to four years of education, Indians had very little participation in schools (ibid.). The colonial government did not assist Indian education prior to 1916 , because "the prevailing colonial attitude was that it would be self-defeating to educate the Indians as they had been taken to Fiji to be an unskilled workforce" (ibid.). While this would normally be seen not only as discrimination against the Indian population but also a reason for Indian bitterness towards the British rulers, it actually was a blessing in disguise. It forced many community minded individuals and religious organisations to engage in self-help education with very humble beginnings and eventually rising to a world class education system today.

It is said that "Wairuku Primary School (then known as Wairuku Indian School) in Ra was the first Indian School established in Fiji in 1898 by the late Badri Maharaj, a farmer and politician who came to Fiji as an indentured laborer in 1889" (Simmons, 2016). Not only did the Indian children attend this school, but it is said the late Ratu Sir Lala Sukuna (a native Fijian Chief) attended this school as well (ibid.). Similar informal schools in individual homes, religious centres and bures emerged in other parts of the country as well. Vatulaulau Sanatan Dharam Primary School in Ba is said to have commenced in 1911 (Vatulaulau Sanatan Dharam Primary School, https://hif.wikipedia.org/wiki/ Vatulaulau_Sanatan_Dharam_Primary_School).

Most Indian schools have thus been established on the initiative of local communities who have formed school committees and have raised funds to build and maintain the schools (Brief History of Education in Fiji, http://shodhganga.inflibnet.ac.in/ bitstream/10603/58925/11/11_chapter\%203.pdf). Sanatan Dharam schools have also been independently built and managed by committees made of members of different branches of the Sanatan Dharam religious faith in Fiji. Today, Sanatan Dharam primary and secondary schools are found in most parts of the two major islands of the country.

"The first formal schools for Indians were started in 1898 by Methodist Mission and the Marist Brothers" [Moag, (1978), p.11]. By 1916, Anglicans and Indian religious groups as the Arya Samaj and Muslims also commenced operating schools for Indians. The involvement of Indian organisations in education marked the beginning of a self-generated demand for education which only gained momentum in the decades that followed (ibid.).

Arya Samaj, also known as the Arya Pratinidhi Sabha of Fiji, was the first Indian organisation to decide to establish a school in 1916 and built the first substantive school, Gurukul Primary School, for Fiji Indians in Saweni, Lautoka in 1918 (Arya Samaj in Fiji, https://en.wikipedia.org/wiki/Arya_Samaj_in_Fiji). In 1972, a secondary school named Pandit Vishnu Deo Memorial College was also built at the site and in 2005, the University of Fiji was also established at the same location (Gurkul Primary School, https://en.wikipedia.org/wiki/Gurkul_Primary_School). Today, the Sabha also owns and manages 14 pre-schools, 18 primary schools, seven secondary schools, a commercial school, a religious training centre as well as a youth development centre (ibid.).

The Fiji Muslim League had its first school, the Islamic Girls School, already existing in 1926 which is now known as Suva Muslim Primary School. "Today, the Fiji Muslim League owns and operates 17 primary and 5 secondary schools, plus a tertiary institution known as the Islamic Institute of the South Pacific" (Islam in Fiji, https://en.wikipedia.org/wiki/Islam_in_Fiji; Alshawabka and Sharma, 2020).

The first Sangam Schools commenced operations at the Subrahmanya Swami Temple in Nadi in March 1927. Like many other informal schools of that time, "there were also clusters of schools running for the South Indians prior to this in Tagi Tagi, Tavua in a 
thatched bure and in Ra. M. N. Naidu was running his own private school in Namoli, Lautoka as well" (Sangam Schools, http://www.sangamfiji.com.fj/index.php?page= sangam-school). The Sangam continued its pursuit to provide higher education and became "the first non-government organization to start a private secondary school, the Shri Vivekananda High School, on 9 March 1949" (South Indians in Fiji, https://en.wikipedia.org/wiki/South_Indians_in_Fiji).

At the 2013 Annual Sangam Convention, it was reported that Sangam now "runs 21 primary schools, five secondary schools and one tertiary institution, namely the nursing school in Labasa" (Goundar, 2016). "Some 10,000 children attend Sangam schools which are open to students of all races without any discrimination whatsoever" (ibid.). People educated in Sangam schools can be found in all walks of life, in all professions and occupations today (ibid.), including the one of the authors of this paper.

The Sikhs built their first school, the Khalsa High School, in Ba in 1958 which is now a multi-racial and co-educational institution open to students of all communities (Sikhism in Fiji, https://en.wikipedia.org/wiki/Sikhism_in_Fiji\#Sikh_schools_in_Fiji). "The Guru Nanak Khalsa Parimary School was also built at the same site in Ba. A small school, the Naduri Bay Khalsa Primary School, was built near Sigatoka to provide for the needs of the small Sikh community in the area. The Guru Nanak Khalsa Primary School opened in Labasa in 1970" (ibid.).

The colonial government did not assist with the education of Indians because they wanted Indians to remain an unskilled workforce. It appears that early Indian education by the Indians themselves made little effort to turn themselves into a skilled workforce. Instead, the principal aim of setting-up schools by different communities was to learn, preserve and promote their languages, cultures and religions. Over time, however, the focus shifted from cultural education to common national education curriculum with English as the main medium of instruction. It is this education that paved the way for most of the descendants of the indentured Indian labourers out of the cane farms and liberation from continuing indenture system.

\section{Conclusions}

Although the indenture system was abolished in 1917, the sugar industry continued with new forms of controls over labour and complex mathematical formulae and accounting methods for sharing the proceeds from sale of sugar and molasses. This included an unfair contract the growers were forced to sign against their will as well as millers taking out not only all their expenses but also inflated amounts of depreciation from the proceeds of sugar before the growers received anything.

The ongoing dispute was eventually heard by Lord Denning whose award pleased the growers but upset the millers so much that they left the country. Then, between the coups of 1987 and 2006, many descendants of indentured labourers were liberated when they were evicted from their sugar cane farms, although they could not comprehend their freedom until many years later. The silent and yet the most powerful of all liberators was self-help education that paved the path for most descendants of indentured labourers out of the cane farms and into trade, business, government and greener pastures abroad.

Future research on this topic could profitably compare other contexts in which workers have been controlled and exploited. In particular, of interest would be the interface of accounting and indentured labour on plantations in other British colonies 
such as Malaysia, West Indies and Mauritius to examine how the calculative practices of accounting are used to govern workers on other colonial plantations. It will be useful to also study the livelihood of indentured labour after the indenture system.

\section{References}

1987 Fijian Coups D'état [online] https://en.wikipedia.org/wiki/1987_Fijian_coups_d'\%C3\% A9tat (accessed 17 September 2019).

300 Fiji Farmers Reported Evicted in Vanua Levu Lease Expiry (2003) 25 November [online] http://www.radionz.co.nz/international/pacific-news/146302/300-fiji-farmers-reportedevicted-in-vanua-levu-lease-expiry (accessed 1 July 2018).

Ali, A. (2004) Girmit: Indian Indenture Experience in Fiji, Ministry of National Reconciliation and Multi-ethnic Affairs, Suva, Fiji.

Alshawabka, Z. and Sharma, U. (2020) 'Quranic hermeneutics: a new Islamic methodology to understanding accounting qualitative data within the Islamic world context', International Journal of Critical Accounting, Vol. 11, No. 3, pp.217-232.

Armstrong, P. (1994) 'The influence of Michel Foucault on accounting research', Critical Perspectives on Accounting, Vol. 5, No. 1, pp.25-55.

Arnold, P. and Hammond, T. (1994) 'The role of accounting in ideological conflict: lessons from the South African divestment movement', Accounting, Organisations and Society, Vol. 19, No. 2, pp.111-126.

Arya Samaj in Fiji [online] https://en.wikipedia.org/wiki/Arya_Samaj_in_Fiji (accessed 20 September 2019).

Brief History of Education in Fiji [online] http://shodhganga.inflibnet.ac.in/bitstream/10603/58925/ 11/11_chapter\%203.pdf (accessed 15 October 2019).

Bryer, R. (2006) 'Accounting and control of the labour process', Critical Perspectives on Accounting, Vol. 17, No. 5, pp.551-598.

Carnegie, G.D. and Napier, C.J. (1996) 'Critical and interpretive histories: Insights into accounting's present and future through its past', Accounting, Auditing and Accountability Journal, Vol. 9, No. 5, pp.7-39.

Chan, A.F. (2015) 'America never abolished slavery', The Huffington Post, 2 May [online] http://www.huffingtonpost.com/angela-f-chan/america-never-abolished-slavery_b_6777420. html.

CSR A 3.0/2/9, National Archives of Fiji, Suva.

CSR F 1.0/2/4, National Archives of Fiji, Suva.

Denning, R.H.L. (1970) The Award of the Rt. Hon. Lord Denning in the Fiji Sugar Cane Contract Dispute 1969, Government of Fiji.

Fleischman, R.K. and Tyson, T.N. (2000) 'The interface of race and accounting: the case of Hawaiian sugar plantations, 1853-1920', Accounting History, Vol. 5, No. 1, pp.7-32.

Forde, K.R. and Bowman, B. (2017) 'Exploiting black labor after the abolition of slavery', The Conversation, 7 February [online] http://theconversation.com/exploiting-black-laborafter-the-abolition-of-slavery-72482.

Foucault, M. (1979) Discipline and Punish the Birth of the Prison, Penguin Books, London.

Foucault, M. (1991) 'Governmentality', in Burchell, G., Gordon, C. and Miller, P. (Eds.): The Foucault Effect Studies in Governmentality with Two Lectures by and an Interview with Michel Foucault, pp.187-204, The University of Chicago Press, Chicago, IL.

Galenson, D.W. (1984) 'The rise and fall of indentured servitude in the Americas: an economic analysis', The Journal of Economic History, March, Vol. 44, No. 1, pp.1-26 [online] http://www.colorado.edu/ibs/es/alston/econ8534/SectionIII/Galenson,_The_Rise_and_Fall_of _Indentured_Servitude_in_the_Americas.pdf. 
Gopal, A. (2014) 'Day that changed Fiji', Fiji Times Online, Wednesday, 14 May.

Goundar, P. (2016) 'Keep your culture. The challenge for South Indians in Fiji', Fiji Times Online 18 January [online] http://www.fijitimes.com/story.aspx?ref=archive\&id=338105.

Gurkul Primary School [online] https://en.wikipedia.org/wiki/Gurkul_Primary_School (accessed 10 September 2019).

Hooks, J.J. and Stewart, R.E. (2007) 'The geography and ideology of accounting: a case study of domination and accounting in a sugar refinery in Australasia, 1900-1920', Accounting Historian Journal, Vol. 34, No. 2, pp.143-168.

Indentured Labour from South Asia (1834-1917) [online] http://www.striking-women.org/module/ map-major-south-asian-migration-flows/indentured-labour-south-asia-1834-1917 (accessed 15 April 2019).

Indian Indenture Ships to Fiji [online] https://en.wikipedia.org/wiki/Indian_indenture_ships_ to_Fiji (accessed 12 October 2019).

Islam in Fiji [online] https://en.wikipedia.org/wiki/Islam_in_Fiji (accessed 15 September 2019).

James, K. and McKenzie, J. (2018) 'A Marxist analysis of American gun culture', International Journal of Critical Accounting, Vol. 10, No. 6, pp.491-518.

Kim, S.N. (2004) 'Imperialism without empire: silence on contemporary accounting research on race/ethnicity', Critical Perspectives on Accounting, Vol. 15, No. 1, pp.95-133.

Lawrence, S., Low, M. and Sharma, U. (2010) 'Prem Sikka and the media: using the media to hold accountants to account', Qualitative Research in Accounting and Management, Vol.7, No. 3, pp.249-269.

Low, M., Kabasunakatuba, L.L. and Sharma, U. (2013) 'The challenges to taxing e-commerce: a comparative analysis for the Pacific', African Journal of Accounting, Auditing and Finance, Vol. 2, No. 4, pp.334-359.

Maynagh, M. (1981) Brown or White? A History of the Fiji Sugar Industry, 1873-1973, Australian National University, Canberra.

Miller, P. (1990) 'On the interrelations between accounting and the state', Accounting, Organisations and Society, Vol. 15, No. 4, pp.315-338.

Miller, P. and Rose, N. (1990) 'Governing economic life', Economic and Society, Vol. 19, No. 1, pp.1-31.

Moag, R.F. (1978) 'Vernacular education in Fiji', South Pacific Journal of Teacher Education, Vol. 6, No. 2, pp.134-139.

Preston, A., Chua, W.F. and Neu, D. (1997) 'The diagnosis-related group prospective payment system and the problem of government rationing health care of the elderly', Accounting, Organisations and Society, Vol. 22, No. 2, pp.147-164.

Ramesh, S. (2007) Fiji, 1987-2007: The Story of Four Coups, 30 April [online] http://www.worldpress.org/Asia/2773.cfm (accessed 31 March 2019).

RBF Quarterly Review (2006) [online] http://www.rbf.gov.fj/ (accessed 10 November 2019).

RBF Quarterly Review (2010) [online] http://www.rbf.gov.fj/ (accessed 10 November 2019).

RBF Quarterly Review (2014) [online] http://www.rbf.gov.fj/ (accessed 10 November 2019).

RBF Quarterly Review (2015) [online] http://www.rbf.gov.fj/ (accessed 10 November 2019).

RBF Quarterly Review (2016) [online] http://www.rbf.gov.fj/ (accessed 10 November 2019).

Reconstruction [online] http://www.history.com/topics/american-civil-war/reconstruction (accessed 30 March 2019).

Reddy, N. (2003) 'Survival strategies for the Fiji Sugar industry', Fijian Studies: A Journal of Contemporary Fiji, Vol. 1, No. 2, pp.265-285.

Refugee Colonies for Evicted Farmers in Fiji (2000) 5 December [online] http://www. saipantribune.com/index.php/9664e3f7-1dfb-11e4-aedf-250bc8c9958e/ (accessed 15 September 2019).

Sanadhya, T. (1914) My 21 Years in the Fiji Islands, Fiji Museum, Suva, Fiji. 
Sangam Schools [online] http://www.sangamfiji.com.fj/index.php?page=sangam-school (accessed 10 August 2019).

Sharma, U. (2013) 'The turn in accounting and business education: neoclassical dominance to Buddhist economics', International Journal of Critical Accounting, Vol. 5, No. 6, pp.623-640.

Sharma, U. and Hoque, Z. (2001) 'Implementing the balanced scorecard in government: the housing authority of Fiji', Journal of Cost Management, Vol. 15, No. 4, pp.37-41.

Sharma, U. and Irvine, H. (2016) 'The social consequences of control: accounting for indentured labour in Fiji 1879-1920', Qualitative Research in Accounting and Management, Vol. 13, No. 2, pp.130-158.

Sherborne, C. (2008) Coup-Coup Land [online] https://www.themonthly.com.au/issue/2008/ october/1268176558/craig-sherborne/coup-coup-land (accessed 10 June 2019).

Sikhism in Fiji [online] https://en.wikipedia.org/wiki/Sikhism_in_Fiji\#Sikh_schools_in_Fiji (accessed 15 July 2019).

Simmons, M. (2016) 'First Indian school boasts famous alumni', The Fiji Times Online, Sunday, 24 April [online] http://www.fijitimes.com/story.aspx?ref=archive\&id=350924.

Slavery Abolished in America [online] http://www.history.com/this-day-in-history/slaveryabolished-in-america (accessed 15 November 2019).

South Indians in Fiji [online] https://en.wikipedia.org/wiki/South_Indians_in_Fiji (accessed 2 March 2018).

Tinker, A.M. (1985) Paper Prophets, Praeger, New York.

Vatulaulau Sanatan Dharam Primary School [online] https://hif.wikipedia.org/wiki/Vatulaulau_ Sanatan_Dharam_Primary_School.

Vicencio, E.R. (2018) 'Conformation of the primitive accumulation and capitalist spirit: theory of corporate governmentality', International Journal of Critical Accounting, Vol. 10, No. 5, pp.394-425.

Vollmer, H. (2003) 'Bookeeping, accounting, calculative practice: the sociological suspense of calculation', Critical Perspectives on Accounting, Vol. 14, No. 3, pp.353-381.

\section{Notes}

1 These are various religious organisation of predominantly Indian population in Fiji. 